Mathias Onischka, Christa Liedtke, Nino David Jordan

\title{
How to sensitize the financial industry to resource efficiency considerations and climate change related risks
}

Originally published as:

Mathias Onischka, Christa Liedtke, Nino David Jordan (2012):

How to sensitize the financial industry to resource efficiency considerations and climate change related risks

In: Journal of Environmental Assessment Policy and Management, Vol. 14, No. 3

(September 2012) 1250017 (26 pages) 
Mathias Onischka $^{a}$, Christa Liedtke $^{\mathrm{a}}$, Nino David Jordan ${ }^{\mathrm{a}^{*}}$

How to sensitize the financial

industry to resource efficiency

considerations and climate change related risks

a Wuppertal Institute for Climate, Environment and Energy; Wuppertal

* Corresponding author: Nino David Jordan, Wuppertal Institute for Climate, Environment and Energy, Döppersberg 19, 42103 Wuppertal

E-mail: nino.jordan@wupperinst.org

Phone: +49020 2492208

Fax: +4920229492138 


\title{
HOW TO SENSITIZE THE FINANCIAL INDUSTRY TO RESOURCE EFFICIENCY CONSIDERATIONS AND CLIMATE CHANGE RELATED RISKS
}

\author{
Mathias Onischka, Christa Liedtke, Nino David Jordan* \\ Wuppertal Institute, Wuppertal, Germany \\ Journal: Journal of Environmental Assessment Policy and Management \\ Manuscript Type: Research Paper in publication \\ *nino.david.jordan@wupperinst.org
}




\begin{abstract}
Increasing resource efficiency can potentially deliver important economic and environmental benefits. Many of these benefits are regularly foregone because the financial sector's capacity to adequately take the opportunities and risks arising from resource utilization and related climate change aspects into account has so far remained relatively undeveloped. Focusing on the case of Germany, a number of barriers to the inclusion of resource efficiency and climate change aspects into financial services' considerations are presented. Corresponding measures for improving the capacity of the financial sector to better integrate resource efficiency considerations and climate change related risks into its operating procedures are introduced. The measures encompass the areas of risk controlling, company reporting, institutional reporting requirements, as well as additional supporting measures.
\end{abstract}

Keywords: resource efficiency; climate change; financial; risk controlling; reporting requirements; policy

\title{
1. Introduction
}

Financial market regulation can significantly contribute towards incentivising firms to produce in less polluting and more resource efficient ways. The concurrent financial, economic and environmental crises open up possibilities for a better alignment of the different policy fields concerned. Taking Germany as an example, we show how policy makers can shape the incentive structures of financial market actors towards a greater consideration of climate risks and resource 
efficiency. From a macro-economic perspective the financial sector could make an important contribution towards reaching the ambitious targets for rising resource efficiency. In order to reach these targets, massive investments in resource efficient and thus more climate friendly technologies will be necessary (see e.g. BMU and Roland Berger, 2008). However, if resource efficiency is not given the necessary consideration in investment and financing decisions, the potential for resource efficiency improvements cannot be fully realized.

In the following section we will explain how anthropogenic resource consumption and climate change are interrelated. We will also discuss the benefits and limitations of increasing resource efficiency. In Section 3 we will then analyse how financial companies currently take the issues of climate change risks and of resource efficiency and conservation into account. In doing so, we will draw comparisons between carbon and general resource performance factors that financial market actors might want to consider when assessing firms. Following this, in Section 4, we will describe the professional circumstances and ethical considerations that have formed the background conditions for the policy recommendations in the subsequent chapters. In Section 5 we will discuss barriers to the inclusion of resource efficiency considerations by the financial service industry and propose a number of strategies for addressing them. These strategies touch upon issues of risk controlling, company reporting and institutional reporting requirements. The advocated policy mix will then be completed with a number of supporting measures in Section 6 .

We focus mainly on how to modify existing financial sector regulation in Germany in order to induce financial services firms to consider resource efficiency factors more strongly in their investment and lending decisions. Where applicable, we also refer to possibilities for integrating climate change related risk in such decision-making. In order to be as concrete as possible we only consider the case of Germany here. However, it would certainly be of interest to start a de- 
bate on the commonalities and differences of various regulatory frameworks for financial markets and their implications for potential reforms targeted towards achieving higher resource efficiency.

\section{Promises and Pitfalls of Resource Efficiency}

The use of natural resources, including energy sources, is the major driving force behind anthropogenic climate change and biodiversity loss. Energy and material use are closely interlinked, as energy is needed at all stages of the value chain, from resource extraction to consumption and, ultimately, waste management. Since all inputs into the industrial metabolism will eventually become outputs, strategies for increasing resource efficiency are more holistic approaches towards reducing environmental impacts than just focussing on specific problems on the output side, like carbon emissions (see Schmidt-Bleek, 1994 and 2009). Often, end-of-pipe technologies designed to reduce emissions actually result in even more energy and resource consumption ${ }^{1}$. In contrast to this, cutting down on material input leads to a reduction in energy input and a corresponding reduction in greenhouse gas (GHG) emissions. Thus, companies can substantially reduce their GHG emissions by increasing their resource efficiency. The concept of resource productivity can be very appealing for businesses as it shifts the focus from spending money on technical efforts for cleaning up wastes and emissions to saving money by spending less on natural resource inputs ${ }^{2}$. One can also increase competitiveness by cutting down on materials costs. Businesses can become more resilient by raising their resource productivity and thereby shielding themselves against price hikes and resource bottlenecks. The systemic effects of this approach are

\footnotetext{
${ }^{1}$ Catalytic converters for cars are a prominent example in this regard.

${ }^{2}$ Businesses pay three times for waste products: from the extraction of raw materials over processing to waste management or disposal.
} 
not only limited to the activity of the individual firm in question but extends to the entire value chain in which the life cycle of a product or service is embedded.

From a micro-economic perspective one could talk of a win-win situation between business and the environment (Weizsäcker et al., 1997). However, this relation becomes more subject to complex interdependencies at the macro level.

Basically, the concept of "resource efficiency" refers to producing the same (or increased) amount of an output $\mathrm{Y}$ with a decreased (or the same) amount of an input $\mathrm{X}$; therefore, it can be deemed a polymorphic concept (Aamodt and Nygård, 1995; Schmidt-Bleek, 1994, 2009; SeilerHausmann et al., 2005; Sloman, 2010). However, different value systems, preferences and theories of physical or social processes can lead to highly divergent assessments of the degree to which a resource is being efficiently utilized. Thus, the practical meaning of resource efficiency would remain rather void without specifying the content of these input and output variables. Although resource efficiency can be subject to very diverse practical interpretations, it is certainly a compelling policy objective:

i. Resource efficiency for reasons of absolute resource scarcity: the deposits of nonrenewable resources can eventually become subject to depletion or their extraction may become more costly with time, which will result in rising market prices (Görlach and Schmidt, 2009).

ii. Resource efficiency for micro-economic reasons: a major share of the manufacturing industry's total costs is due to material requirements. With increased resource efficiency factor productivity rises and companies can improve their competitiveness by reducing costs. Therefore, the efficient utilization of resources can be of decisive importance for a 
business in order to remain competitive (ADL et al., 2005; Liedtke, 2005; Rennings et al., 2008; Ayres and Warr, 2009).

iii. Resource efficiency for macro-economic reasons: when resources are only available to a limited extent on a state's territory, a more efficient use of resources can positively affect the trade balance. This can support the economy's resilience to external shocks by alleviating the impact of fluctuations in commodity prices (Bleischwitz et al., 2009).

iv. Resource efficiency as a contribution against climate change and for general environmental reasons: economic activities are often accompanied by enormous material flows. Resource extraction, refinement, transport, utilization, and disposal contribute significantly to the emission of GHGs and other undesirable environmental effects (see Bringezu and Bleischwitz, 2009; Rockström, 2010).

v. Resource efficiency for reasons of global distributional and intergenerational justice: the utilization of the earth's resources is unevenly distributed, both with regard to the present situation and with regard to future generations. This has led to calls for a more equitable arrangement (see e.g. Schmidt-Bleek, 1994, 2008).

vi. Resource efficiency as a means of conflict prevention: if increased resource efficiency leads to reductions in absolute resource demand, it can help to prevent conflicts that might otherwise arise from the "scramble for resources" (see e.g. Bleischwitz and Bringezu, 2008). 
Increasing resource efficiency can - ceterus paribus - help to reduce resource consumption. However, due to the rebound effect, some of the savings from more resource efficiency are offset by increased utilization. Sometimes this might even reach a situation known as the Jevons paradox: the actual efficiency savings are rendered negative by increased utilization (Binswanger, 2001; Polimeni, 2009; Meyer, 2009). Because increases in resource efficiency spur economic growth, and economic growth in turn spurs demand for resources, savings in resource efficiency can easily be offset by growth-induced overall consumption increases.

Resource efficiency in itself would need to continuously increase faster than the expansion of the economy takes place in order to reach an absolute decoupling of welfare development from material throughput. So far only a relative decoupling has taken place; an absolute decoupling would probably require far-reaching changes across many of the parameters that constitute our modern economies (Schmidt-Bleek 1994; Weizsäcker et al., 1997; Daly, 2004; Jackson, 2009).

Recent strategy papers by international organisations advocate for less environmentally damaging industrial trajectories and emphasize the importance of raising resource and carbon productivity (European Commission, 2011; OECD, 2011; UNEP, 2011). However, the linkage between material and energy consumption has so far failed to receive much public attention.

\section{Status quo: financial companies' consideration of climate change risks and of resource efficiency and conservation}

Huge potentials for increases in resource efficiency remain unexplored because financial service providers usually do not sufficiently consider resource efficiency aspects as part of their investment and lending criteria. 
We start from the assumption that the financial sector usually only shows interest in natural resource conservation if it pays off in monetary terms, meaning it either contributes towards making a profit or towards reducing risks. Of course, there are also exceptions from the rule. Some financial services operators might offer green investment due to genuine ethical considerations ${ }^{3}$. There is some evidence that capital markets already reward the overall risk reduction associated with improved environmental performance, which is due to more efficient resource utilization and lower risks from potential future regulation and litigation.

Conducting a study of 267 US firms, Sharfman and Fernando (2008) found that financial markets reward firms for better environmental risk management. This reward comes mainly in the form of a reduction in the cost of equity. With regard to debt capital, the relation is not as straight forward. Increased environmental risk management is positively associated with the cost of debt capital. However, at the same time firms are allowed to take on increased leverage. This helps to increase tax subsidies and, potentially, to outperform competitors. Sharfman and Fernando conclude that an improved environmental risk management strategy does not only result in increased resource efficiency but also in an improved risk profile vis a vis financial markets.

Ambec and Lanoie (2008) also argue that greener firms might be able to enjoy lower costs of capital. One reasons is that they have easier access to capital markets by virtue of their inclusion in the portfolios of "green" or ethical mutual funds. Another reason is that greener companies can borrow more easily from banks. Many banks now have experts evaluating the environmental performance of borrowers. These experts in particular scrutinize potential liabilities that could arise from the contamination of assets. Beyond this, shareholders might respond to information on the environmental performance of companies by adjusting their preferences and thereby causing changes in the costs of capital. Conducting a meta-analysis of 16 portfolio analyses, 14 event

\footnotetext{
${ }^{3}$ In particular customer-held cooperative banks like GLS Bank or the non-publicly traded Triodos Bank seem to exhibit genuine ethical commitment.
} 
studies and 12 long-term studies, Ambec and Lanoie conclude that the large majority of these studies "show that better environmental performance is associated with better financial performance (or at least not worse)". Supporting this, the Carbon Disclosure Project's (2011) Global 500 Report 2011 "suggests a strong correlation between higher financial performance and good climate change disclosure and performance".

Particularly large and diversified institutional investors like pension funds, mutual funds and insurance companies ("Universal Owners") have an interest in reducing their exposure to environmental damage. Due to their immense power in contemporary capitalism, the policies adopted by financial companies can exert massive influence on manufacturers. Glattfelder (2010) analysed the global ownership network of transnational corporations (TNCs). He shows that the world's top economic actors are highly interconnected. Furthermore, "most of the top power-holders are financial intermediaries“. Such a high degree of diversification and interconnectivity will find its expression in specific interest structures. A fully-fledged discussion of this interest structure is beyond the scope of this article. However, a recent joint report by the investor initiative Principles for Responsible Investment (PRI) and the United Nations Environmental Programme Finance Initiative (UNEP FI) is suggestive of how such an interest structure might unfold with regard to certain environmental externalities: Because of "Universal Owner's" huge and widespread portfolios a “company's [environmental] externalities can damage the profitability of other portfolio companies, adversely affecting other investments, and hence overall market return" (PRI Association and UNEP FI, 2011). Therefore, an interest in influencing companies to minimize certain environmental externalities might arise.

However, it is clear that environmental and resource efficiency aspects are not transparent and comparable enough, yet, to take them fully into account. Making the resource efficiency perfor- 
mance of companies more amenable to systematic comparisons and evaluations should help to direct investment flows into more resource efficient directions.

Recently, financial companies have started to pay considerable attention to climate change related risks. In comparison, awareness of resource efficiency and conservation issues is still in its infancy. In the following we will discuss some of these climate change related aspects, as resource consumption and climate change are strongly interlinked. We suggest that financial companies' behaviour towards climate change issues can be used partly as a blueprint and partly as a contrasting picture for an analysis of possible incentives for increasing resource efficiency.

\section{Financial companies' consideration of climate change risks}

Financial companies are exposed to climate change risks in various ways. Insurers of homes and businesses are directly exposed to these risks while banks or other investors can be indirectly affected when climate-related risks cause loans to go bad or share prices to fall. While the field of CSR is largely driven by companies' concern about their reputation, corporate approaches to climate change are strongly shaped by pressures from investors (Newell and Paterson, 2010).

Companies see themselves confronted with different types of risks arising from climate change. Attention focuses on three different types of risks (see e.g. International Finance Corporation, 2010):

i. Risks arising from firms' active contribution to climate change, e.g. in the form of litigation or reputational losses. Reputational losses might impinge on access to important markets and litigation can become costly. 
ii. Risks arising from firms' dependence on activities that contribute towards climate change, e.g. in the form of price hikes for fossil fuels or emission permits or the failure to anticipate new government regulation early enough in advance.

iii. Risks arising from firms' exposure to the impacts of climate change. There is a wide array of weather-related risks that might impinge on businesses' ability to pay back their loans. As a consequence, they might consider to withdraw from coasts or increasingly flood-prone rivers or to adapt architectural designs in order to prepare for increased risks from hurricanes. More and more companies in climate sensitive sectors such as tourism or agriculture are including climate change scenarios in their strategic calculations.

Furthermore, a lack of responsiveness to the opportunities arising from decarbonisation also harbours the risk of foregoing potential new market opportunities.

A number of large multi-national companies do respond to mounting pressure to deliver on their green rhetoric and try to reduce environmental liabilities. However, the great number of small and medium-sized enterprises (SMEs) does not see climate change or resource conservation as issues to be addressed by their operational activities. Neither are they under as much scrutiny as the multi-nationals nor do they command over the resources to comply with demanding standards or to launch elaborated PR campaigns (Newell and Paterson, 2010). Where individual companies would otherwise lack incentives to enhance their climate and resource performance, financial companies could potentially leverage some influence.

According to Newell and Paterson (2010), the financial community has adopted four sets of strategies in response to climate change: 
i. Withdraw: Some insurance providers have simply withdrawn coverage from some regions and clients.

ii. Risk management: This can involve limiting, sharing, pooling or hedging the risks of climate impacts.

iii. Investment in action on climate change: The response to the danger of reputational losses comes largely in the form of corporate social responsibility (CSR) schemes. This might entail engaging one's critics and perhaps even forming partnerships with them. Some companies seem to be involved in the funding of climate adaption projects. Another approach to CSR is building up a climate portfolio. J.P. Morgan, for example, simply bought up Climate Care, one of the largest producers of carbonoffset credits. Many leading financial actors have declared themselves 'carbon neutral' as part of their CSR strategy.

iv. Demanding transparency and emissions reductions from companies: Large institutional investors have started to pressure companies to be transparent about their emissions and to limit or reduce them.

Concrete actions by financial companies have been varied: Barclays Capital, for example, already screens its investments along the lines of climate change risks. HSBC, the largest bank in emerging markets, is carefully observing the effect climate changes might have on the economies where it invests. Responding to shareholder pressure, J.P. Morgan has actually started assessing the financial risks associated with GHG emissions in loan evaluations (Newell and Paterson, 2010; HSBC, 2009).

The benchmarking of companies' carbon emissions was initially developed by members of UNEP FI. Such benchmarking enables investors to use data on emissions, which they can base 
their investment decisions on. One assumption is that even without taking climate change into account, regulatory and other risks make more $\mathrm{CO} 2$ intensive companies riskier than less intensive companies (Newell and Paterson, 2010). We suggest that this assumption could be extended to companies' dependence on scarce resources as well as with regard to the impact of their activities on natural resource depletion.

Until now, insurers in the US are not subject to insurer-specific obligations regarding the disclosure of climate change risks. Only a minority of them has climate change policies in place (Ceres, 2011). However, the US Securities and Exchange Commission (SEC) already forces stock-listed companies to disclose their $\mathrm{CO}_{2}$-intensity. Specifically, potential impacts of legislation, regulation, international accords, indirect consequences of regulation, business trends, and physical impacts of climate change may trigger disclosure requirements (Environmental Leader, 2010; Newell and Paterson, 2010; SEC, 2010).

In Germany, the Commercial Code (Handelsgesetzbuch) requires stock exchange listed companies to consider climate risk in their risk management and to disclose such risks in their annual reports and their sales prospectuses. Similar obligations apply for investment funds. However, similar to the situation in the US, in most cases it would be difficult for litigant investors to prove causality in front of a court (Holz, 2010).

Although there are certain initial requirements for reporting on climate risks in the USA as well as in Germany, there are as of yet no obligations for systematic reporting. Therefore, it is far from astonishing that a recent survey among financial institutions from around the world found that climate risks related information is so far insufficient for adequate approaches to risk management (Sustainable Business Institute and UNEP Finance Initiative, 2011). 


\title{
Financial companies' consideration of resource efficiency and conservation
}

\author{
We argue that the risks structure arising from companies' resource use can be usefully compared
}

to the risks arising from carbon emissions.

This is illustrated in table 1.

Tab. 1: Overview of analogies between risks arising from resource use and carbon emissions

\begin{tabular}{|c|c|c|}
\hline Type of risk & Carbon emissions & Resources use \\
\hline $\begin{array}{l}\text { Risks that arise regardless of } \\
\text { one's own contribution (exo- } \\
\text { genous). }\end{array}$ & Weather risks. & $\begin{array}{l}\text { Weather risks, habitat loss, resource } \\
\text { conflicts. }\end{array}$ \\
\hline $\begin{array}{l}\text { Potential litigation and/or } \\
\text { reputational losses. }\end{array}$ & $\begin{array}{l}\text { Risks arising from firms' active } \\
\text { contribution to climate change. }\end{array}$ & $\begin{array}{l}\text { Risks arising from firms' direct or } \\
\text { indirect contribution to climate } \\
\text { change, habitat loss and resource con- } \\
\text { flicts. } \\
\text { Because resources are often simply } \\
\text { bought on the (rather anonymous) } \\
\text { world market, the perceived risk of } \\
\text { liabilities is low. However, companies } \\
\text { are more and more held morally re- } \\
\text { sponsible in case they neglect the } \\
\text { consequences of their resource acqui- } \\
\text { sition patterns. This can translate in } \\
\text { companies being perceived as "clean- } \\
\text { er" or "dirtier" than others. These risks } \\
\text { vary substantively depending on the } \\
\text { class of products concerned (branded } \\
\text { sports apparel is a product class more } \\
\text { sensitive to reputational losses than } \\
\text { copper tubes). }\end{array}$ \\
\hline $\begin{array}{l}\text { Risks arising from dependence } \\
\text { on certain acitivities. }\end{array}$ & $\begin{array}{l}\text { Price hikes for fossil fuels or emis- } \\
\text { sion permits or the failure to antici- } \\
\text { pate new government regulation (e.g. } \\
\text { emission cap adjustments) early } \\
\text { enough in advance. }\end{array}$ & $\begin{array}{l}\text { Price hikes or bottlenecks (for political } \\
\text { reasons or because of absolute scarci- } \\
\text { ty) for energy and material resources } \\
\text { more generally or emission permits or } \\
\text { the failure to anticipate new govern- } \\
\text { ment regulation (e.g. resource taxes, } \\
\text { green procurement) early enough in } \\
\text { advance. }\end{array}$ \\
\hline $\begin{array}{l}\text { Foregoing of new market } \\
\text { opportunities. }\end{array}$ & $\begin{array}{l}\text { Due to lack of responsiveness to the } \\
\text { opportunities arising from decarbon- } \\
\text { isation. }\end{array}$ & $\begin{array}{l}\text { Due to lack of responsiveness to the } \\
\text { opportunities arising from decarboni- } \\
\text { sation and dematerialisation. }\end{array}$ \\
\hline
\end{tabular}


Considering these analogies, the financial sector is so far not systematically taking into account the risks and opportunities that arise from differences in firms' resource productivity and dependence.

According to qualitative interviews conducted by Görlach and Zvedov (2010) within the framework of our overarching research project, resource efficiency considerations do not play a role in German banks' lending activities yet. This appears to be somewhat astonishing as for companies receiving credits resource efficiency is becoming more and more relevant for remaining competitive (ADL et al. 2005; Modi and Mishra, 2011).

Even with regard to risk assessment, where qualitative aspects can also play a role, the topic is hardly considered; systematic procedures or binding obligations are lacking.

With regard to equity investments, there are already a number of "green funds" catering for the German market that explicitly consider resource efficiency as part of their investment criteria (see e.g. GLS Bank, 2011; Umweltinvestmentfonds.de, 2011).

However, a lack of systematic and comparable resource efficiency related reporting requirements makes it relatively difficult for investors to take such considerations into account.

\section{Writing Policy: Concrete Steps}

This article is based on a policy paper commissioned by the German Federal Environment Agency (UBA) and the German Federal Ministry for the Environment, Nature Conservation and Nuclear Safety. We aim at providing the greatest transparency with regard to how we arrived at our policy proposals. However, policy analysis as conducted by environmental 'think tanks' can be likened to a ,clinical profession' along the lines of medicine, psychology or law, where the cognitive disposition of the analyst, the shared epistemology of policy practitioners and the corre- 
sponding tacit knowledge all have a role to play (Geva-May, 2005). Policy analyses commissioned by a ministry or a federal agency are, of course, quite distinct from those written for purely academic purposes. As they aim at formulating new policies or modifying existing ones, the main emphasis is on problem definition, the plausible consequences of policies, and - last but not least - their political feasibility. In this vein, Greenberg (2007) suggests six criteria for judging environmental policy proposals commissioned by public institutions:

i.anticipated reactions by politicians and public officials,

ii.anticipated reactions by the general public and interests groups such as non-governmental organisations, industry and the media,

iii.environmental and health aspects,

iv.short and long term economic costs and benefits,

v.normative aspects,

vi.flexibility and time pressure.

Bearing these criteria in mind, we combined a literature review with qualitative expert interviews (Görlach and Zvedov, 2010) in order to generate an empirical basis for our policy proposals. The proposals were then subjected to evaluation by an expert workshop. The final selection of the instruments was taken in association with the clients, i.e. the German Federal Environment Agency (UBA) and the German Federal Ministry for the Environment, Nature Conservation and Nuclear Safety (BMU). The results should therefore, like all policy recommendations, be interpreted as hybrids of science and politics (on research institutes as hybrid organizations see Gulbrandsen, 2011).

\section{Barriers to the Inclusion of Resource Efficiency Considerations by the Financial Service \\ Industry and Strategies for Addressing Them}


In the following we will analyse some major barriers to the inclusion of resource efficiency considerations by the financial service industry. Based on this, we will make some pragmatic proposals on how to slightly modify extant incentives structures so that financial market actors are more likely to pay attention to the benefits of resource efficient production.

The marginal role of resource efficiency and related reporting in the financial sector can be attributed to the following reasons:

i. Central stakeholders do not demand a resource related reporting from their customers.

ii. The economic risks and opportunities associated with resource related questions have not yet been given sufficient consideration (Görlach and Schmidt, 2010).

iii. Financial service firms do not have concrete incentives and obligations to integrate the resource utilization of their customers into their operational activities, in particularly not into their risk management.

One might argue that the price signals from carbon and commodity markets should provide sufficient incentives for companies to adjust their activities in the direction of more resource efficiency and less carbon intensity. However, the European Union Emission Trading Scheme (EU ETS) is a politically instituted market whose emission prices are heavily dependent on the politically determined quantity of certificates. These politically determined prices do not reflect climate specific portfolio risks. Commodity prices also fail to reflect future scarcity by not accurately accounting for ecological thresholds and irreversibilities in depleting natural capital. Also, if environmental externalities were internalised, commodity prices would be much higher (Neumayer, 2000). Future regulatory developments might well seek to internalize externalities, possibly provoking commodity price hikes. 
The existence of comprehensive, comparable and reliable information on the resource utilization by companies is a fundamental prerequisite for a systematic consideration of resource efficiency aspects on part of the financial sector. Here, financial service firms depend on the data reported by the companies. So far, initiatives for systematically surveying resource specific data have neither been clearly focused on the needs of the financial industry nor have they been particularly successful in their implementation (see e.g. Bierter et al., 2001).

Usually, firms only report selectively within the framework of environmental and sustainability reporting. Furthermore the reported data is not sufficiently homogenous to be amenable to systematic comparisons. Firms do not have concrete incentives to reveal information on their resource utilization in an adequate quality, among other reasons because:

i. adequate resource related reporting requires additional time and resources while not providing tangible benefits;

ii. there are no uniform reporting standards with sufficiently meaningful and verifiable indicators.

On the other hand, there is a very concrete disincentive to reveal too much information on resource utilization as it is considered to be of strategic value.

In the following sections we will analyse different barriers to the inclusion of resource efficiency considerations by the financial services industry and propose approaches for overcoming these. We limit our analysis to the case of Germany. However, due to important cross-national similarities in financial market institutions we expect our analysis to be relevant in other countries as well. 


\subsection{Risk controlling}

Risk controlling features belong to the central functions of financial services firms and directly impinge on decisions regarding conditions and volumes of financing as well as on the strategic orientation of firm operations. So far risk controlling is not sufficiently connected to relevant risk related variables concerning resource or climate aspects.

The models that banks usually employ for company evaluation do not sufficiently reflect the causal relations between resource utilization and climate impacts and possibly related uncertainties and risks. This is because only frequentistic approaches are obligatory. Standard evaluations are based on historical data in the following:

i. fundamental company evaluation (in discounted cash flow models as well as in multiple ratings (see Onischka and Schweneke, 2008)),

ii. common credit rating systems within banks,

iii. assessments by rating agencies,

iv. the different models for the quantification of credit and market risks according to Basel II. $^{4}$

When risk contributions resulting from resource utilization and climate change are to be taken into account, a purely empirically based risk exposure analysis without prospective adjustments cannot do justice to the factors at hand. Due to its context sensitivity the historical data simply cannot be relied on (Onischka, 2008; Bundesregierung, 2008).

\footnotetext{
${ }^{4}$ Basel III didn't bring direct changes regarding climate or resource related risks as the focus was on liquidity and solvency risks.
} 
Expert-based approaches can factor in potential future developments into the evaluation. These are sometimes employed when the credit volume is particularly large. However, the reliance on individual experts in such cases still does not boil down to a systematic consideration of resource related risks. Therefore, there is still a tendency of under-estimating these risks.

\section{Recommended Strategy}

We argue that the most effective strategy for approaching this issue would be to modify the regulatory framework. However, such a more comprehensive step might not be politically feasible at the moment. Therefore, we start with some suggestions for taking better advantage of the possibilities within the existing regulatory framework.

i. Concrete recommendations for taking better advantage of the possibilities within the existing regulatory framework

a. Haircuts ${ }^{5}$ : based on the market value of the securities one could perform assetrelated, general haircuts (Basel II No 133ff) in order to account for expected value losses due to resource utilization patterns.

b. Rating agencies: the banking authorities could demand a stronger consideration of resource and climate risks in order to grant an operating license to rating agencies (Basel II No. 90 ff.).

c. IRB: one could use an internal rating-based approach (IRB) in order to either quantitatively evaluate the future impact of resource utilization on project success,

\footnotetext{
${ }^{5}$ When an asset is being used as a collateral, a percentage is subtracted from its market value in order to reflect the risk associated with holding the asset. The percentage subtracted is called a haircut. The size of the haircut depends on the perceived riskiness of the asset.
} 
profitability etc. or qualitatively evaluate according to criteria such as strategic positioning, market analysis or regulation scenarios.

ii. Concrete recommendations for a modification of the existing regulatory framework

a. Opening clauses for alternative market-based risk models: many general and specific regulations ask for the verification and stress tests of processes and methods on the basis of historical data. The exclusive focus on historical data leads to an underestimation of resource and climate related risks. The same goes for market price models that are used for the calculation of haircuts for securities or for the probability of default (PD) with the IRB. Insofar as one deems it desirable to continue using vector autoregressive (VAR) models one would need to find possibilities for integrating simulations of resource price and climate trends on the basis of historical data, particularly with regard to the probability of sudden shocks. A first step should be the introduction of opening clauses for alternative market price models.

b. Institution of new market-based risk models: with reference to Basel II only frequentistic approaches are being used. In contrast to the aforementioned opening clauses one could also make alternative approaches obligatory, at least for specific applications or risks. Some promising approaches for the management of risks are already being developed within the scholarly community (Jaeger et al., 2003, Krause, 2007, Günther et al., 2006, Mercer, 2011). Such new methods for the quantification and evaluation of risks should not be exclusively based on historical data but should also aim to take into account future developments to the extent that it is possible. Here, further model building and tests are necessary before such 
models can be integrated within the regulatory framework. The academic community as well as the financial industry, e.g. the Bank for International Settlements (BIS), could contribute significantly to the development of such models.

c. Limitation of netting positions: resource and climate specific risks usually add to the conventional market and credit risks and increase the overall risks. Of course, there are winners as well as losers resulting from such a modification of risk assessments. However, because these risks can be very heterogeneous over time and across sectors a netting of risk contributions only makes sense to a certain extent (Steinbrügge, 2007). At the moment it is possible to perform a netting of the claims and liabilities of either the same counterparty or of balance sheet positions. Consequently, only the net position is used to calculate the debt-equity ratio (Basel II No. 188 and 309). A netting can lead to uncovered risks when claims and liabilities are allocated the same risk class on the basis of the current approach but would fall into different classes if resource and climate risks were part of the calculation. Consequently, it would be worth considering examining any relevant differences with regard to operating sites, sectors, etc., as well as the climate and resource risk exposure of each position prior to a netting. Perhaps a limitation of nettings to positions within the same sector would also do. As an alternative, one could consider applying a small haircut to the positions that are to be netted.

d. Explicitly addressing risks related to resources, climate and the environment in the regulatory framework: in the extant regulatory framework explicit risk categories are not clearly mentioned. However, it would be a possibility to directly address risks relating to resources, climate and the environment in the regulatory framework. This means the general requirements for risk management would demand 
that such risks also be covered. In the beginning, the concrete operational implementation would not need to be addressed. The explicit mentioning of such risks would already be a clear signal to the financial sector that the regulator deems such risks to be of significance. This could deliver an impetus to the financial sector to initiate corresponding considerations and developments.

If one wants to go beyond the possibilities that are available within the scope of the implementation of EU law it would be necessary to seek European and / or international coordination. Since the German government and the EU orient their regulation according to the proposals emanating from international expert discussions, de facto it is necessary to insert regulatory reform proposals into such expert discussions.

The aforementioned proposals differ with regard to their impact on resource efficiency improvements and with regard to the resistance that can be expected from the financial industry, financial authorities and the financial expert community. 
Tab. 2: Overview of specific proposals for the regulation of the financial industry's risk management

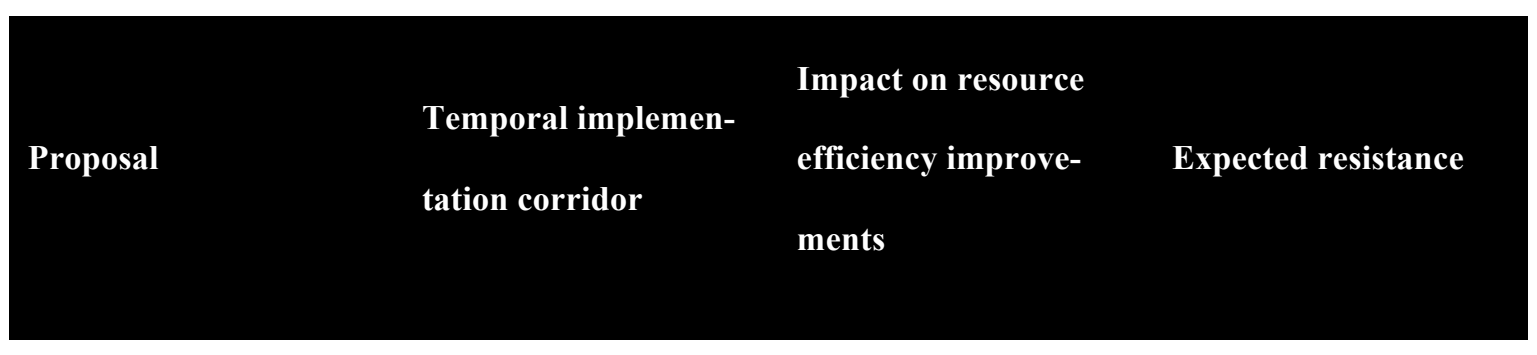

1. Recommendations in the frame of the existing regulatory framework
I) hair cuts
short term
low
medium

Ii) rating agencies

short term

high

low

iii) IRB

mid to long term

medium

high

2. Recommendations for a modification of the existing regulatory framework
iv) opening clauses
short to mid term
medium
low to medium

v) new market-based risk

models

long term

high

high

vi) netting

mid to long term

low

high

vii) mandatory declara-

tions of resource related

mid term

medium

low

risks 


\subsection{Company reporting}

The existing practice of company reporting with regard to resource efficiency can be improved by including non-financial performance indicators in reporting requirements.

Any elaboration of possible strategies towards that direction needs to depart from a survey of the status quo. The following aspects characterize the latter:

i. Current reporting requirements are insufficient: although relevant laws already explicitly demand that non-financial key performance indicators (KPI) be integrated into the company report, most companies present such information - if at all - separately in the voluntary part of the company report, with significant differences regarding content and credibility.

ii. Auditing of non-financial indicators is not common: non-financial indicators can contain important information with regard to an understanding of the situation and the likely development of a company, and to the chances and risks emanating from climate change and resource utilization aspects. According to the logic of current reporting requirements all KPI should be subject to auditing and therefore should belong to the auditable part of the company report, which can be understood as an instrument of creditor protection (Baetge, 2008).

iii. Definitions of performance indicators are missing: currently, there is a lack of binding non-financial performance indicators that could express a company's resource utilization. So far there have been several attempts by different actors to define sector wide KPIs (Hesse, 2007; DVFA, 2007a,b; DEFRA, 2006). However, these indicator sets are either 
too abstract and general, or in parts too comprehensive for practical implementation or conceptualized from the perspective of specific applications (e.g. fundamental financial analysis). Therefore, important prerequisites for a balanced cross-sector application are missing. As a result, an immediate implementation of such indicator sets cannot be recommended. However, parts of them can be used in order to create sector-specific KPIs.

iv. Companies have a lot of leeway: currently it is up to the individual companies whether they choose to include one of the aforementioned KPIs, define new KPI sets, or do not include any at all. This means that the companies decide if and how non-financial performance indicators are included in their reporting.

\section{Recommendations for increasing resource efficiency}

In order to overcome the aforementioned barriers, it is necessary

i. to either introduce an obligation for companies to publish explicitly defined resource related KPIs in their reporting,

ii. or to achieve the development of a professional standard that defines the requirements for financial and non-financial KPIs in company reporting.

Both are only possible against the background of a dedicated and detailed framework for resource and sustainability reporting.

It is therefore necessary to elaborate, either via self- or government regulation a catalogue of basic indicators that should be reported across sectors. In that way it will be possible to bench- 
mark different companies against each other. From a long term perspective, in order to guarantee the international comparability of company reporting, it would be desirable to work towards an internationally acknowledged standard.

\subsection{Institutional reporting requirements}

From a juridical point of view, the stock exchanges in Germany are public institutions, i.e. they are governed by public law. However due to self-administration they are de facto governed by a mix of private and public law. While the organizational structure of the different stock exchange bodies and their duties and obligations are prescribed by public law, the implementation remains in the hands of a private stock company, e.g. Deutsche Börse AG. That means that the public stock exchanges are run by private companies und not by the government itself (Tolkmitt, 2007).

Each stock exchange differentiates between different market segments for which there are different conditions for listings, transparency and reporting obligations and monitoring and regulation regimes. A higher market segment is supposed to signal to investors that a company is of higher "quality". The categorization in a higher market segment, particularly the prime standards, is also a condition for the inclusion in stock indices, e.g. the DAX. ${ }^{6}$

For companies the differences in transparency and reporting requirements are the central difference between the market segments (see Tab. 2).

\footnotetext{
${ }^{6}$ Blue chip stock market index consisting of the 30 major German companies trading on the Frankfurt Stock Exchange
} 
Tab. 2: Selected transparency and publication requirements according to market

\section{Standard General Standard Prime Standard}

Annual report/ semi-

annual report

Simple ad-hoc-

notifications
Annual report / semi-

annual report within

four months

Quarterly reports

Extended ad-hoc notifi-

cations in German

Declaration of direc-

tor's dealings

Mandatory offer after

change of control
Annual financial statement according to international accounting standards (IFRS/IAS or US-GAAP)

Detailed quarterly reports according to the guidelines defined by the stock exchange rules.

Company calendar

At least one analyst conference per year

Ad-hoc notifications in English 


\section{Recommendations for increasing recourse efficiency}

Considering the central role of stock market exchanges it would be a plausible approach to introduce additional reporting requirements for market segments with high transparency obligations. This would mean that listed companies would need to reveal additional resource and climate relevant information in addition to their current reporting requirements. As a result, financial service firms could include this information in their investment and financing decisions.

\section{Supporting Measures}

A significant increase in resource efficiency will be most likely when the different strategies are applied in a comprehensive and concerted fashion. In order to adequately complement this, additional supporting measures are necessary. For the coming years we deem the following supporting measures to be particularly relevant:

i. Efficiency campaign: an efficiency campaign in cooperation with relevant financial market related institutions could approach financial market actors in a targeted fashion and raise their awareness for issues of resource efficiency.

ii. Federal Resource and Climate Data Institution: the introduction of a federal institution charged with the continuous development of methods, the surveying of resource and climate relevant data, inter-institutional cooperation and the satisfaction of further stakeholder needs.

iii. Commission of enquiry: a parliamentary commission of enquiry on resource efficiency and sustainability in the financial sector could analyse current and future challenges for 
the financial sector and policy making and elaborate possible responses together with experts in matters of finance, economics, law, ecology and ethics.

\section{Conclusion}

The success of policy strategies for increasing resource efficiency will be limited as long as there is no sufficient steering of capital flows into resource efficient technologies and business models. In order for the financial sector to exert its influence on businesses in ways that motivate them to increase their resource efficiency, the following conditions need to be fulfilled:

i. Companies need to provide sufficient and comparable information so that the potential financial repercussions of their resource utilization can be evaluated.

ii. Regulation must make it easier for financial service firms to include the risks and opportunities emanating from patterns of resource utilization in their evaluations.

Although these are necessary conditions, they cannot guarantee a significant effect and need to be accompanied by additional supporting measures such as efficiency campaigns, institutions dedicated to resource and climate issues and parliamentary commissions working towards financial sector reform.

The main strategies could be implemented at a relatively low price for the government because only regulatory changes would need to be made. The supporting measures would be more costly, in particular the establishment of a Federal Resource and Climate Data Institution. For businesses, the regulatory burden would clearly increase. However, the transition from a "cowboy economy", with seemingly unlimited resources, towards a "spaceman economy", which is adjusted to the 
reality of the earth's finite resource base, will not proceed without demanding greater accountability from all those who profit from the extraction and utilization of resources (see Boulding, 1966).

With regard to the relation between economic costs and environmental benefits we cannot give precise estimates. The system to which our proposals pertain is very complex and the consequences should be subject to highly dynamic and interdependent developments. In favour of our proposals we can say that increasing resource efficiency may not only deliver environmental but also economic benefits, not least in the form of increased resilience to resource price hikes and bottlenecks. More efficient and resilient companies can contribute to a more resilient overall economy. Furthermore, the incremental approach to reform helps to split uncertainties into manageable chunks.

The difficulty in the implementation of the main measures arises less from budgetary constraints than from the necessity for cross-ministerial coordination: Financial market policy needs to be coordinated with environmental policy (on the need for policy integration see also Hamdouch and Depret, 2010). In order for market actors to link the topics of finance and resource efficiency, politics must take that step first.

Many analysts as well as public opinion have identified the urgent need for fundamental readjustments in the regulation of financial markets (Krugman, 2008; Roubini and Mihm, 2010). At the same time, the dramatic environmental impacts of our current development model are increasingly conceded. Moments of crisis also hold opportunities for reform, particularly when once sealed agreements again become objects of negotiation. Considering the depth of the current economic crisis and the correspondingly large scope of potential reform endeavours, we hope that 
this contribution will help to stir debate and creative thinking on how to better align environmental policy with financial market regulation.

\section{Bibliography}

Aamodt, A and M Nygård (1995). Different roles and mutual dependencies of data, information, and knowledgeAn AI perspective on their integration. Data \& Knowledge Engineering, 16(3), 191-222.

ADL, Wuppertal Institut and FhG ISI (2005). Studie zur Konzeption eines Programms für die Steigerung der Materialeffizienz in mittelständischen Unternehmen. Abschlussbericht, Bonn 2005. [A study for the conceptualisation of a programme for increasing material efficiency in SMEs]

Ambec, S and P Lanoie (2008). Does it pay to be green? A systematic overview. The Academy of Management Perspectives (formerly The Academy of Management Executive)(AMP), 22(4), 45-62.

Ayres, RU and B Warr (2009). The Economic Growth Engine: how energy and work drive material prosperity. Cheltenham: Edward Elgar.

Baetge, J and A Hesse (2008). Best Practices bei SD-KPIs, im Auftrag von Deloitte, Düsseldorf, München 2008. [Best practices for sustainable development key performance indicators]

Bierter, W, G Irgang, C Manstein, F Schmidt-Bleek, N Eisenmenger, F Hinterberger, M Kuhndt, C Liedtke, S Moll and M Ritthoff (2001): Machbarkeitsstudie für den Aufbau von "PROREGIS" ( Productivity registry - center for resource productivity factors for wealth creation). Wien. URL:

http://www.seri.de/documentupload/pdf/dl2 proregis.pdf [Study on how to realise the establishment of a productivity registry center for resource productivity factors for wealth creation (PROREGIS)]

Binswanger, M (2001). Technological progress and sustainable development: what about the rebound effect? Ecological Economics, 36(1), 119-132.

Bleischwitz, R, S Bringezu (2008). Global governance for sustainable resource management. Minerals and Energy, 23(2), 84-101.

Bleischwitz, R, B Bahn-Walkowiak, S Bringezu, R Lucas and S Steger (2009). Outline of a resource policy and its economic dimension. In Sustainable Resource Management : global trends, visions and policies, S Bringezu (ed.), pp. 216-296. Sheffield : Greenleaf Publishing.

BMU and Roland Berger (2009). GreenTech made in Germany 2.0 - Umwelttechnologie-Atlas für Deutschland. München. [Environmental Technology Atlas for Germany]

Boulding, KE (1966). The economics of the coming spaceship earth. In Environmental Quality in a Growing Economy, H Jarrett (ed.), pp. 3-14. Baltimore, MD: Johns Hopkins University Press.

Bringezu, S and R Bleischwitz (2009). Sustainable Resource Management : global trends, visions and policies. Sheffield: Greenleaf.

Bundesregierung (2008). Deutsche Anpassungsstrategie zum Klimawandel. Verabschiedet am 17.12.2008; URL: http://www.bmu.de/files/pdfs/allgemein/application/pdf/das gesamt.pdf [German Climate Change Adaption Strategy]

Carbon Disclosure Project (2011). CDP Global 500 Report 2011. Accelerating Low Carbon Growth. URL: https://www.cdproject.net/CDPResults/CDP-G500-2011-Report.pdf

Ceres (2011). Climate Risk Disclosure by Insurers. Evaluating Insurer Responses to the NAIC Climate Disclosure Survey. A Ceres Report. Boston: Ceres. URL: http://www.ceres.org/naic-climate-report

Daly, H (2004). Ecological Economics : principles and applications. Washington: Island Press.

Department of Environment, Food and Rural Affairs (DEFRA) (2006). Environmental Key Performance Indicators. London.

Deutsche Börse AG (2008). Ihr Weg an die Börse - ein Leitfaden. Frankfurt: Deutsche Börse AG. [Your way to the Stockmarket: a guide] 
DVFA (2007a). Key Performance Indicators (KPIs) for Extra-/ Non-Financial Reporting. DVFA Financial Papers $08 / 07$.

DVFA (2007b). Intermediate Results - Concept of Key Performance Indicators. Frankfurt.

Environmental Leader (2010). Insurers Released From Mandatory, Public Climate Change Risk Disclosures. URL: http://www.environmentalleader.com/2010/03/31/naic-backs-down-from-mandatory-publicclimate-change-risk-disclosures/ [Accessed September 13, 2011].

European Commission (2011). A Resource-Efficient Europe - Flagship Initiative Under the Europe 2020 Strategy. $\operatorname{COM}(2011)$ 21. Brussels: European Commission. URL: http://ec.europa.eu/resource-efficienteurope/pdf/resource efficient europe en.pdf

Geva-May, I (2005). Thinking like a policy analyst: policy analysis as a clinical profession. In Thinking Like a Policy Analyst. Policy Analysis as a Clinical Profession, I Geva-May (ed.), pp. 15-50. New York: Palgrave Macmillan.

Glattfelder, JB (2010). Ownership Networks and Corporate Control. Mapping Economic Power in a Globalized World. A Dissertation Submitted to the ETH Zurich. Diss. ETH No. 19274. Zurich.

GLS Bank (2011). Die GLS Anlagekriterien. URL: http://www.gls.de/unsereangebote/vermoegensmanagement/anlagekriterien.html [Accessed October 20, 2011]. [The GLS Bank Investment Criteria]

Görlach, S and M Schmidt (2010). Maßnahmenvorschläge zur Ressourcenpolitik im Bereich unternehmensnaher Instrumente: Feinanalysepaper für den Bereich Efficiency Awareness \& Performance. Arbeitspapier zu Arbeitspaket 4 des Projekts „Materialeffizienz und Ressourcenschonung “ (MaRess). Wuppertal: Wuppertal Institut für Klima, Umwelt, Energie. [Proposals for Business Related Resource Policy Instruments: indepth analysis for the area of efficiency awareness and performance. Working Paper for Work Package 4 of the Project „Material Efficiency and Resource Conservation“]

Görlach, S and D Zvedov (2010). Stimmen aus der Praxis: Ergebnisse aus den begleitenden Gesprächen mit Intermediären und Unternehmen zum Thema Ressourceneffizienz. Arbeitspapier zu Arbeitspaket 4 des Projekts "Materialeffizienz und Ressourcenschonung" (MaRess). Wuppertal: Wuppertal Institut für Klima, Umwelt, Energie. [Voices from the Field: results of accompanying interviews with intermediaries and companies on resource efficiency. Working Paper for Work Package 4 of the Project „Material Efficiency and Resource Conservation"]

Greenberg, MR (2007). Environmental Policy Analyis and Practice. New Brunswick, New Jersey and London: Rutgers University Press.

Gulbrandsen, M (2011). Research institutes as hybrid organizations: central challenges to their legitimacy. Policy Sciences, (44)3, 215-230.

Günther, E, G Weber, M Nowack and S Arndt (2006). Unternehmenssteuerung im klimapolitischen Umfeld (CO2Navigator). Dresdner Beiträge zur Betriebswirtschaftslehre. Dresden: TU Dresden. [Steering Firms in the Context of Climate Policy]

Hamdouch, A and M Depret (2010). Policy integration strategy and the development of the 'green economy': foundations and implementation patterns. Journal of Environmental Planning and Management, 53(4), 473-490.

Hesse, A (2007). Nachhaltig mehr Wert, im Auftrag von Deloitte und dem Bundesumweltministerium. München. [Sustainably more Value, commissioned by Deloitte and the German Federal Ministry for the Environment]

Holz, S (2010). Anleger und Klimarisiken. Rechtliche Ansprüche auf dem Finanzmarkt am Beispiel von Aktienund Investmentgesellschaften. Bonn: Germanwatch. URL: www.germanwatch.org/corp/auk.htm [Investors and Climate Risks: a discussion of legal entitlements in the financial market drawing on the example of joint stock and investment companies]

HSBC (2009). Too close for comfort. The HSBC Climate Vulnerability Assessment-mapping risks for the G-20 in 2020. London: HSBC. URL:

http://www.research.hsbc.com/midas/Res/RDV?p=pdf\&key=3nn8vfg91h\&n=255808.PDF

International Finance Corporation (2010). Climate Risk and Financial Institutions. Challenges and Opportunities. Washington: International Finance Corporation. URL: 
http://www.ifc.org/ifcext/sustainability.nsf/AttachmentsByTitle/p_ClimateRiskandFIsFullreport/\$FILE/IF CClimate_RiskandFIs_FullReport.pdf

Jaeger, C, J Krause, A Haas, R Klein and K Hasselmann (2003). A method for computing the fraction of attributable risk in view of climate damages with an application to the alpine heat wave. Risk Analysis, (28) $4,815-823$.

Jackson, T (2009). Prosperity Without Growth : economics for a finite planet. London: Earthscan.

Krause, J (2007). Agricultural Yield Expectations Under Climate Change - A Bayesian Approach. Berlin: Humboldt Universität.

Krugman PR (2008). The Return of Depression Economics and the Crisis of 2008. London: Penguin Books.

Labatt, S and RR White (2007). Carbon Finance: the financial implications of climate change. New York: Wiley.

Liedtke, C and T Busch (2005). Materialeffizienz : Potenziale bewerten, Innovationen fördern, Beschäftigung sichern. München: Ökom. [Material Efficiency: evaluating potentials, promoting innovations, securing employment]

Mercer (2011). Climate Change Scenarios - Implications for Strategic Asset Allocation. Mercer. URL: $\mathrm{http} / / / \mathrm{www} \cdot \mathrm{mercer} . \mathrm{com} / \mathrm{climatechange}$

Meyer, B (2009). Costing the Earth?: perspectives on sustainable development. London: Haus.

Modi, SB and S Mishra (2011). What drives financial performance - resource efficiency or resource slack?: evidence from U.S. based manufacturing firms from 1991 to 2006, Journal of Operations Management 29(3), 254-273.

Moneva, JM and E Ortas (2008). Are stock markets influenced by sustainability matter? Evidence from European companies. International Journal of Sustainable Economy, 1(1), 1-16.

Moneva, JM and B Cuellar (2009). The value relevance of financial and non-financial environmental reporting. Environmental and Resource Economics, 44(3), 441-456.

Neumayer, E (2000). Scarce or abundant? The economics of natural resource availability. Journal of Economic Surveys. 14(3), 307-335.

Newell, P and M Paterson (2010). Climate Capitalism. Global Warming and the Transformation of the Global Economy. New York: Cambridge University Press.

OECD (2011). Towards Green Growth. Paris: OECD. URL: http://www.oecd.org/dataoecd/37/34/48224539.pdf Onischka, M (2008). Environmental and climate risks in financial analysis. In Papers presented at the Second Int. Conf. on Environmental Economics and Investment Assessment, K Aravossis (ed.), pp. 75-85. Southampton.

Onischka, M and M Schweneke (2008). Messung und Anwendung von Risikoinformationen in der Finanzanalyse, Portfoliomanagement und Risikomanagement. Wuppertal: Wuppertal Institut für Klima, Umwelt, Energie. [Measuring and Applying Risk Information in Financial Analysis, Portfolio Management and Risk Management]

Polimeni, J (2009). The Myth of Resource Efficiency : the Jevons paradox. London: Earthscan.

PRI Association and UNEP Finance Initiative (2011). Universal Ownership. Why Environmental Externalities Matter to Institutional Investors. Geneva: UNEP Finance Initiative.

Rennings, K, C Rammer, U Oberndorfer and K Jacob (2008). Instrumente zur Förderung von Umweltinnovationen. Umwelt, Innovation, Beschäftigung. Berlin: Umweltbundesamt. [Instruments for Promoting EcoInnovations. Environment, Innovation, Employment]

Rockström, J (2010). Planetary Boundaries. New Perspectives Quarterly, 27(1), 72-74.

Roubini, N and S Mihm (2010). Crisis Economics : a crash course in the future of finance. New York: Penguin Press.

Schmidt-Bleek, F (1994). Wieviel Umwelt braucht der Mensch? : MIPS - das Maß für ökologisches Wirtschaften. Berlin: Birkhäuser. [How Much Environment Does Mankind Need?: MIPS, the indicator for ecological economic management]

Schmidt-Bleek, F (2009). The Earth : natural resources and human intervention. London: Haus.

SEC (2010). SEC Issues Interpretive Guidance on Disclosure Related to Business or Legal Developments Regarding Climate Change. Press Release January 27, 2010. URL:

http://www.sec.gov/news/press/2010/2010-15.htm [Accessed September 13, 2011] 
Sharfman, MP and CS Fernando (2008). Environmental risk management and the cost of capital. Strategic Management Journal, 29(6), 569-592.

Stanny, E and K Ely (2008). Corporate environmental disclosures about the effects of climate change. Corporate Social Responsibility and Environmental Management, 15(6), 338-348.

Steinbrügge, J (2007). Optimale Finanzierung nach Basel II. Osnabrück: Gabler. [Optimal Financing According to Basel II]

Sustainable Business Institute and UNEP Finance Initiative (2011). Advancing Adaptation Through Climate Information Services. Results of a Global Survey on the Information Requirements of the Financial Sector. Sustainable Business Institute and UNEP Finance Initiative. URL: http://www.unepfi.org/fileadmin/documents/advancing_adaptation.pdf

Tolkmitt, V (2007): Neue Bankbetriebslehre. Basiswissen zu Finanzprodukten und Finanzdienstleistungen. Wiesbaden: Gabler. [New Banking Management: basic knowledge on financial products and services]

Umweltinvestmentfonds.de (2011). Fondsportrait "Sarasin OekoSar Equity" - Stand Mai 2011. URL: http://www.umweltinvestmentfonds.de/sarasin oekosar equity.html [Accessed October 20, 2011]. [Portrait of the "Sarasin OekoSar Equity" fund]

UNEP (2011). Towards a Green Economy: pathways to sustainable development and poverty eradication. URL: http://www.unep.org/GreenEconomy/Portals/93/documents/Full_GER_screen.pdf

Weizsäcker, EU, A Lovins and H Lovins (1997). Factor Four: doubling wealth - halving resource use. London: Earthscan. 